\title{
EFEKTIFITAS INSTAGRAM SEBAGAI MEDIA PERSUASI FILANTROPI ISLAM BAGI MAHASISWA
}

\author{
Herlina Yustati \\ IAIN Bengkulu \\ Email: hyustati@gmail.com
}

\begin{abstract}
Through this paper the author will measure the effectiveness of Instagram as a media for persuasion of Islamic philanthropy for students. Because Instagram is a social media that is in great demand by the younger generation. This research is a quantitative study with a questionnaire as a research instrument, population for tihis research was students of the zakat waqf management study program of IAIN Bengkulu, sample was a saturated sample, consist of 76 students. Measuring the level of effectiveness using the AIDA method (Attention, Interest, Desire and Action). The results showed that the effectiveness of Instagram was in the good category as a persuasion media for Islamic philanthropy for students.
\end{abstract}

Kata Kunci: effectiveness, Instagram. Islamic philanthropy

Abstrak : Melalui tulisan ini penulis akan mengukur tingkat efektifitas instagram sebagai media persuasi filantropi Islam bagi mahasiswa. Karena Instagram merupakan media sosial yang banyak diminati oleh generasi muda. Penelitian ini merupkan penelitian kuantitatif dengan kuesioner sebagai intrumen penelitian, populasi penelitian adalah mahasiswa program studi zakat dan wakaf IAIN Bengkulu, sampel penelitian merupakan sampel jenuh yaitu sebanyak 76 orang mahasiswa. Pengukuran tingkat efektifitas menggunakan metode AIDA (Attention, Interest, Desire dan Action). Hasil penelitian menunjukkan bahwa tingkat efektifitas instagram berada pada kategori baik sebagai media persuasi filantropi Islam bagi mahasiswa.

Kata Kunci: Efektifitas, Instagram. Filantropi Islam

\section{A. PENDAHULUAN}

Kata "filantropi" merupakan
istilah baru dalam Islam, namun
demikian belakangan ini sejumlah istilah
Arab digunakan sebagai padanannya.
Filantropi kadang-kadang disamakan
dengan al-,,ata" al-ijtima" $i$ yang artinya
pemberian sosial, al-takaful al-insani
yang artinya solidaritas kemanusiaan,
'ata" khayri yang artinya pemberian
untuk kebaikan, atau sadaqah yang
artinya sedekah.

Filantropi secara leksikal berasal dari bahasa Yunani yaitu phylanthropy yang berarti Philos (cinta) dan anthropos

\footnotetext{
${ }^{1}$ Udin Saripudin, "Filantropi Islam," Bisnis 4, no. 2 (n.d.): 165-185, http://mhakicky.blogspot.com/2012/11/filantropiislam.html.
}

(manusia), sehingga mengandung arti cinta manusia atau mencintai dan peduli pada sesama manusia. Filantropi secara luas diartikan sebagai tindakan atau usaha untuk meningkatkan kesejahteraan manusia lewat berbagai bentuk bantuan dan sumbangan, atau secara esensial sama dan lebih dikenal sebagai kedermawanan sosial atau kesetiakawanan sosial. $^{2}$

Tradisi filantropi Islam setidaknya bisa dipahami dengan dua cara yakni, Pertama, kedermawanan yang bersifat

\footnotetext{
${ }^{2}$ Yulkardi et al., "Filantropi Untuk Keadilan Sosial: Sebuah Studi Pendahuluan Tentang Potensi Dan Pola Derma Pada Masyarakat Minangkabau Dan Kemungkinan Pengembangannya Untuk Keadilan Sosial," Jurnal Antropologi, Isu-Isu Sosial Budaya 1, no. $14 \quad$ (2014): $33-38$, http://jurnalantropologi.fisip.unand.ac.id/index.php/ja ntro/article/view/4.
} 
wajib bagi seluruh kaum muslim untuk membayarkannya, yaitu zakat. Kedua, kedermawanan yang tidak bersifat wajib atau sekedar anjuran dalam pembayarannya, yakni melakukan infak, sedekah dan wakaf. ${ }^{3}$

Mensosialisasikan filantropi Islam tidak hanya merupakan ibadah, namun sebagai sumber kontribusi peningkatan kesejahteraan masyarakat Islam. ${ }^{4}$ Saat ini untuk memperoleh pengetahuan tentang filantropi Islam dapat melalui berbagai media. Vin Crosbie menjelaskan ada tiga media komunikasi yang selama ini berlangsung. Pertama, media interpersonal yang disebut one to one. Media ini memungkinkan seseorang saling komunikasi atau tukar informasi dengan seseorang lainnya. Kedua, dikenal sebagai mass media. Media ini digunakan sebagai sarana menyebarluaskan informasi dari satu

${ }^{3}$ Makhrus, "Aktivisme Pemberdayaan Masyarakat Dan Institusionalisasi Filantropi Islam Di Indonesia," Islamadina 13, no. 2, 2014, hlm. 26-44.

${ }^{4}$ Zakat, infaq, shadaqah, dan wakaf adalah bentuk ajaran Islam yang mengajak umat manusia untuk peduli terhadap sesama. Keempat filantropi ini memiliki persamaan yaitu sama-sama bernilai ibadah dan meningkatkan solidaritas antar umat. Keempatnya memiliki peran penting dalam pemberdayaan umat yakni dengan pendayagunaan dana filantropi tersebut dapat me-minimalisir ketimpangan perekonomian masyarakat, mengentaskan kemiskinan, dan meminimalisir pengangguran yang mungkin me-nimbulkan keresahan dalam masyarakat sehingga terwujudlah ma-syarakat yang tentram makmur dan sejahtera. (Qurratul Uyun, Zakat, Infaq, "Shadaqah dan Wakaf sebagai Konfigurasi Filantropi Islam, Islamuna", Volume 2 Nomor 2 Desember 2015, hlm.218) orang ke banyak orang (one to many). Media komunikasi ketiga disebut new media. Media ini merupakan percepatan sekaligus penyempurnaan dari dua media sebelumnya. Lebih jauh media ini digunakan untuk mengkomunikasi ide maupun informasi dari banyak orang ke banyak orang (many to many) (Crosbie: online). Berdasarkan terminologi di atas, karakteristik new media, yakni dapat memberi akses ke konten di mana pun dan kapan pun, bersifat digital dan interaktif. Media ini memberi kesempatan siapa pun untuk berpartisipasi kreatif dan kolektif di dalamnya. ${ }^{5}$ dalam kehidupan sehari-hari new media ini dikenal dengan internet.

Tidak diragukan lagi internet sebagai new media membawa perubahan mendasar pada seluruh aspek kehidupan saat ini. Seolah tidak ada ruang kehidupan yang terhindar dari intervensi kecanggihan teknologi new media. Pengaruhnya jelas merasuk ke segenap nadi kehidupan manusia, baik secara individual maupun hubungan sosial.

Keberagaman media teknologi informasi saat ini menjadi sarana yang paling efektif dalam membentuk persepsi, sikap dan perilaku individu. Hal itu disebabkan oleh kenyataan bahwa hampir

\footnotetext{
${ }^{5}$ Muhammad Jinan, "Intervensi New Media Dan Impersonalisasi Otoritas Keagamaan Di Indonesia," Jurnal Komunikasi Islam 03, no. 02 (2013): hlm. 321-348
} 
disemua kegiatan penyampaian informasi

tersebut selalu menyimpan unsur persuasi yang sering tidak disadari oleh masyarakat sebagai penerima informasi. Beragam bentuk isi pesan dalam informasi yang terdapat dalam media teknologi informasi seperti tayangan di televise, radio, internet maupun media cetak mayoritas memiliki indikasi persuasi yang tujuannya untuk membentuk atau merubah sikap, dan perilaku masyarakat yang dilakukan secara massif. Penggunaan media teknologi informasi modern dan internet telah membuka pintu munculnya pemikiran baru dan kreatif tentang bagaimana mengatur dan merencanakan suatu gerakan sosial yang cepat berpengaruh secara global termasuk gerakan filantropi Islam.

$$
\text { Perkembangan selanjutnya }
$$

sebagai dampak dari new media adalah semakin banyaknya media sosial (social networking $)^{6}$, termasuk di dalamnya

\footnotetext{
${ }^{6}$ Media social (Social Networking) adalah sebuah media online dimana para penggunanya bisa dengan mudah berpartisipasi, berbagi, dan menciptakan isi meliputi blog, sosial network atau jejaring sosial, wiki, forum dan dunia virtual. Blog, jejaring sosial dan wiki mungkin merupakan bentuk media sosial yang paling umum digunakan oleh masyarakat di seluruh dunia. Sementara jejaring sosial merupakan situs dimana setiap orang bisa membuat web page pribadi, kemudian terhubung dengan teman teman untuk berbagi informasi dan berkomunikasi. Jejaring sosial terbesar antara lain Facebook, Myspace, dan Twitter. (Wilga Secsio Ratsja, dkk "Pengaruh Media Sosial terhadap Perilaku Remaja" Prosiding KS: Riset dan PKM Volume 3 Nomor 1: $2016 \mathrm{hlm}$. 50. Penggunaan
}

media sosial filantropi Islam baik yang dikelola oleh lembaga-lembaga maupun oleh individu. Melalui media sosial tersebut dilaksanakan gerakan kedermawanan sosial, misalnya melalui situs seperti http://pusat.baznas.go.id, website izi.or.id (Inisiatif Zakat Indonesia), kitabisa.com, rumahzakat.org, dan lain-lain. Selain menggunakan situssitus tersebut di atas gerakan kedermawanan sosial juga dilakukan melalui jejaring sosial seperti facebook, instagram, youtube, maupun jejaring sosial lainnya.

Beberapa contoh persuasi filantropi Islam yang diviralkan melalui media sosial dan mendapat tanggapan positif dari masyarakat serta gerakan ini bertujuan melakukan penggalangan dana bagi mereka yang membutuhkan seperti donasi untuk saeni $^{7}$,

media sosial memberikan dampak yang sangat positif terutama dalam melakukan interaksi baik secara sosial, politik maupun ekonomi. Penggunaan media sosial memberikan kemudahan dalam berkomunikasi, baik teman, keluarga yang tidak memungkinkan dilakukan melalui face to face karena faktor jarak. Kita dapat mengirimkan informasi-informasi yang dibutuhkan dengan mudah dan cepat, begitu pula dalam mengakses informasi yang kita butuhkan.

${ }^{7}$ Penggalangan untuk saeni diawali karena pada tanggal 10 Juni 2016 dagangan di warung milik Saeni disita Satuan Polisi Pamong Praja. Saeni dianggap melanggar aturan karena menjual makanan di siang hari pada bulan Ramadhan. Hal ini memicu rasa prihatin dan amarah netizen. Karena saeni yang berusia 53 tahun menangis dan memohon agar daganggannya tidak diangkut. Melihat hal ini Seorang pengguna Twitter bernama Dwika Putra (@dwikaputra) pun berinisiatif menggalang dana via Twitter untuk mengganti modal Saeni. Aksi Dwika disambut antusiasme yang tinggi dari netizen. Hanya 
\#KoinUntukAustralia ${ }^{8}, \quad @$ KoinKPK $^{9}$,

Koin Peduli Prita ${ }^{10}$ dan masih banyak

dalam waktu dua hari, dana yang terkumpul mencapai Rp 232 jutaan. (Fatima Kartini Bohang, 4 Penggalangan Dana yang Viral di Medsos, http://tekno.kompas.com/read/2016/06/13/20140027/ 4.Penggalangan.Dana.yang.Viral.di.Medsos

${ }^{8}$ Dua bandar narkoba asal Australia Andrew Chan dan Myuran Sukumuran divonis hukuman mati oleh pemerintah Indonesia pada awal 2012 lalu. Tak terima, Perdana Menteri Australia Tony Abott mengungkit kebaikan negaranya kepada Indonesia. Menurut Abott, Indonesia harusnya membebaskan dua warga negaranya karena dulu Australia pernah mendonasikan duit 1 miliar dollar AS (kini sekitar Rp 13,3 triliun) pasca Tsunami. Warga Aceh sontak merespons pernyataan Abott tersebut dengan gerakan \#KoinUntukAustralia di Twitter. Mereka mengajak seluruh masyarakat Indonesia menyumbang koin untuk mengembalikan duit Australia. Awalnya hanya ada posko di Aceh, lalu meluas hingga ke Jakarta, Padang, Sumatera Barat, dan Kalimantan. Berkarung-karung koin terkumpul dengan nilai mencapai jutaan rupiah. (Fatima Kartini Bohang, 4 Penggalangan Dana yang Viral di Medsos, http://tekno.kompas.com/read/2016/06/13/20140027/ 4.Penggalangan.Dana.yang.Viral.di.Medsos

${ }^{9}$ Komisi Pemberantasan Korupsi (KPK) hendak membangun gedung perkantoran baru pada pertengahan 2012. Pasalnya, gedung kala itu tak sanggup lagi menampung karyawan.

Sayangnya anggaran pembangunannya tersangkut di Dewan Perwakilan Rakyat (DPR). Masyarakat umum akhirnya bergerak sendiri dengan menggalang dana untuk KPK. Gerakan ini diinisiasi secara online dan offline.

ranah online, netizenmembuat

akun@KoinKPK untuk menyerukan pentingnya bantuan ke KPK. Hingga akhir 2012, gerakan ini berhasil mengumpulkan dana sebesar Rp 403 juta. (Fatima Kartini Bohang, 4 Penggalangan Dana yang Viral di Medsos, http://tekno.kompas.com/read/2016/06/13/20140027/ 4.Penggalangan.Dana.yang.Viral.di.Medsos

${ }^{10}$ Gerakan Koin Peduli Prita bisa dibilang sebagai penggalangan dana via media sosial yang paling sukses di Indonesia. Hal ini bersumbu dari rasa simpati netizen atas nasib Prita. Prita diharuskan membayar denda Rp 204 juta kepada Rumah Sakit OMNI. Ia dituduh mencemarkan nama baik rumah sakit tersebut setelah mengeluh atas pelayanan yang diberikan via email. Dalam tiga minggu, netizen bersatu padu mengumpulkan duit hingga Rp 825 juta untuk Prita Mulyasari. Ia adalah seorang ibu yang anaknya dirawat di RS OMNI Internasional Alam Sutera, Tangerang. (Fatima Kartini Bohang, 4 Penggalangan Dana yang Viral di Medsos, gerakan kedermawanan lainnya. Disini terlihat peran media sosial sangat besar dalam mempengaruhi netizen, hanya dengan memunculkan beberapa headline atau artikel di Facebook, beberapa kicauan di Twitter, atau mengunggah video-video di YouTube, secara tidak langsung sudah dapat mempengaruhi orang lain, selanjutnya dengan membagikan artikel tersebut ke sesama teman di akun Facebook, re-tweet kicauan, mengunduh dan menonton video di YouTube, atau hanya dengan menekan tombol "like" maka semakin tersebar informasi tersebut ke semua penjuru. Dan masih banyak contoh gerakan sosial lainnya yang diawali dari media sosial.

Di Indonesia penyampaian informasi sosial melalui media sosial mungkin lebih potensial karena media massa memiliki jangkauan terbatas dalam masyarakat dan tingkat kebiasaan membaca masyarakat Indonesia masih tergolong rendah. Selain itu dari 256,2 Juta Orang penduduk Indonesia, sebanyak 129,2 Juta Jiwa adalah pengguna media sosial. ${ }^{11}$

http://tekno.kompas.com/read/2016/06/13/20140027/ 4.Penggalangan.Dana.yang.Viral.di.Medsos

${ }^{11}$ https://www.apjii.or.id/survei2016 


\section{Hasil Survei APJII \\ Statistik Pengguna Internet Indonesia}

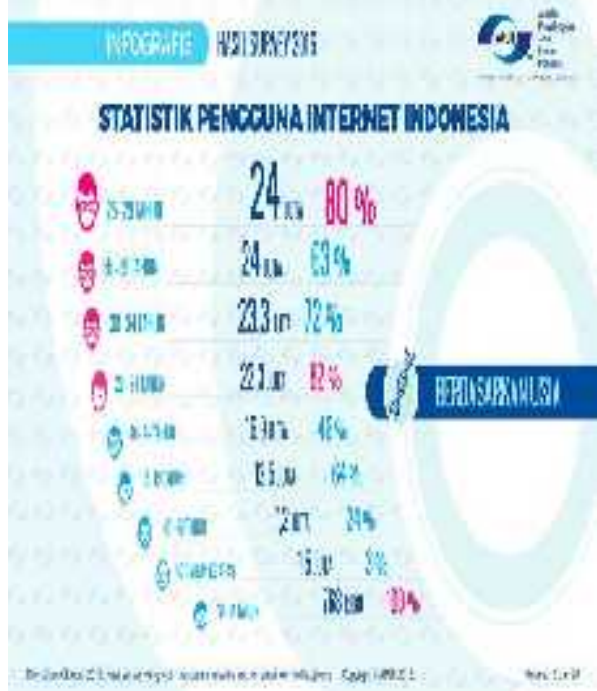

Sumber: https://apjii.or.id/survei2017

Menurut riset yang dilakukan oleh APJII, sebanyak $80 \%$ pengguna internet secara umum adalah anak muda yang berusia 25-29 tahun dan 64\% yang berusia 15-19 tahun. Dan sebanyak 89\% penggunan internet berasal dari mahasiswa. ${ }^{12}$ Generasi muda lebih akrab dengan media baru yang berbasis internet ini dan mayoritas waktu yang dihabiskan oleh generasi muda untuk membuka facebook, Instagram, Youtube, Twitter, Path dan media sosial lainnya dibandingkan dengan membaca melalui media massa.

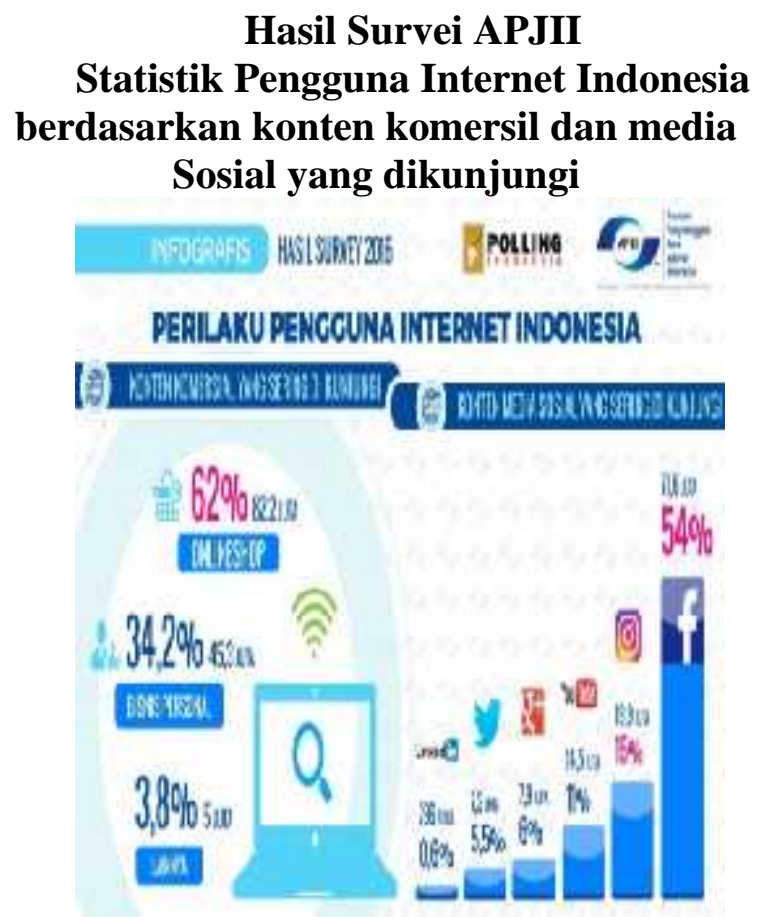

Sumber: https://apjii.or.id/survei2017

Hasil survey di tahun 2016 menunjukkan bahwa facebook, instagram, youtube merupakan media sosial yang paling umum digunakan oleh masyarakat di seluruh dunia, termasuk di Indonesia. Melalui media-media tersebut, publik dapat berkomunikasi, memberi komentar, membuat status, berbagi foto, video, dan lain-lain media-media ini termasuk sangat efektif digunakan sebagai alat komunikasi, alat promosi, serta alat sosialisasi yang dapat memberikan ruang lebih luas.

Dengan kehadiran media sosial yang dapat diakses melalui handphone ${ }^{13}$ dimana saja dan kapan saja, seharusnya menimbulkan efektifitas yang tinggi

\footnotetext{
${ }^{13} 63,1$ Juta Jiwa penduduk Indonesia mengakses internert melalui handphone. https://www.apjii.or.id/survei2016
} 
sebagai sarana untuk mengajak membayar zakat, infaq, sedekah dan wakaf terutama bagi generasi muda. Kehadiran media sosial ini juga memiliki makna yang signifikan bagi generasi muda, dan sangat memungkinkan potensi peningkatan jumlah muzakki dan orangorang yang gemar berbagi di kalangan generasi muda dapat ditingkatkan. Untuk itu dalam hal ini peneliti akan menganalisis efektifitas dan sikap generasi muda terhadap persuasi melalui instagram khususnya dalam filantropi Islam.

\section{B. KAJIAN TEORI}

\section{Efektifitas Persuasi}

Istilah persuasif berasal dari kata dalam bahasa Latin "Persuasio" yang berarti membujuk, mengajak dan merayu. Persuasif adalah kegiatan psikologis yang bertujuan untuk menumbuhkan nilai kesadaran, kerelaan disertai perasaan senang. Persuasi merupakan komunikasi dimana pesan-pesan yang dikirim diharapkan mampu mengubah sikap, kepercayaan, dan perilaku pihak penerima. Definisi lain persuasive adalah kegiatan psikologis untuk merubah sikap, pendapat, atau tingkah laku tanpa menggunakan ancaman, kekerasan, kekuatan, penekanan, pemerasan, pemboikotan, penyuapan, terror dan intimidasi, tetapi menggunakan, empati, kesadaran dan sepenuhnya perasaan. Dalam konteks ini persuasi diartikan sebagai tujuan mengubah sikap dan tingkah laku orang baik dengan lisan maupun tulisan. ${ }^{14}$

Kegiatan persuasi secara lisan misalnya dilakukan melalui dakwah, iklan televisi, iklan radio, dan lainlain. Kegiatan persuasi melalui tulisan dilakukan melalui media cetak seperti Koran, melalui daring seperti media social. Persuasi disini baik lisan maupun tulisan memiliki tujuan yang sama yaitu, mengajak orang lain sesuai dengan tujuan ajakan itu sendiri. Termasuk ajakan filantropi atau kedermawanan yang dilakukan melalui media social. Ajakan ini harus dilakukan dengan efektif agar dapat membuahkan hasil.

Efektivitas merupakan suatu tindakan dari penerima melakukannya dengan sesuatu yang bermakna sesuai dengan yang diinginkan pengirim. Persuasi diartikan sebagai tujuan mengubah sikap dan tingkah laku orang baik dengan lisan maupun tulisan. Persuasif merupakan usaha pengubahan sikap individu dengan

${ }^{14}$ Fatma Laili Khoirun Nida, "Persuasi Dalam Media Komunikasi Massa," At-Tabsyir, Jurnal Komunikasi Penyiaran Islam 2, no. 2 (2014): 77-95. hlm. 79 
memasukkan ide, fikiran, pendapat dan fakta baru lewat pesan-pesan komunikatif. Definisi lain persuasive adalah kegiatan psikologis untuk merubah sikap, pendapat, atau tingkah laku tanpa menggunakan ancaman, kekerasan, kekuatan, penekanan, pemerasan, pemboikotan, penyuapan, terror dan intimidasi, tetapi menggunakan, empati, kesadaran dan sepenuhnya perasaan. $^{15}$ Persuasi merupakan kegiatan mempengaruhi khalayak melalui terpaan terpaan informasi yang diberikan.Kegiatan persuasi tak lepas dari penerapan strategi komunikasi pemasaran.

Dalam komunikasi pemasaran perlu dirumuskan tujuan yang ingin dicapai dari proses komunikasi pemasaran yang akan dilakukan. AIDA merupakan salah satu konsep dalam sebuah pemasaran yang memegang peranan penting. Dengan menggunakan metode AIDA diharapakan dapat mengukur tingkat efektifitas.

a. Attention

Dalam attention ini seorang pemasar haruslah mampu membuat sebuah media informasi agar mengandung daya tarik bagi konsumen.Membuat suatu

\footnotetext{
${ }^{15} \mathrm{Ibid}$.
}

pernyataan yang mengungkap perhatian orang, membuat kata atau gambar yang powerful yang bisa menarik perhatian hingga orang berhenti dan memperhatikan isi pesan berikutnya.

b. Interest

Interest adalah langkah setelah seorang pemasar mampu untuk membuat sebuah media informasi tersebut agar dapat mengandung daya tarik bagi konsumen, seorang pemasar haruslah memikirkan sebuah media informasi agar dapat mengandung minat bagi calon pelanggan atau konsumennya tersebut. Kebanyakan media informasi yang buruk melalaikan dalam melakukan tahapan ini, ditahap inilah sebenarnya target atau konsumen bersedia memberikan waktunya untuk membaca pesan dari pemasar lebih detail.

c. Desire

Selanjutnya langkah yang harus dilakukan oleh seorang pemasar ialah memunculkan keinginan untuk mencoba atau memiliki, dimana dalam tahapan ini pemasar haruslah jeli atau pintar membaca target atau konsumen dalam tahapan ini.Langkah ini untuk membuktikan bahwa seorang 
pemasar mampu memberikan solusi

yang tepat dalam melakukan sebuah keputusan bagi konsumen. Dalam tahap ini khalayak telah mempunyai motivasi untuk memiliki produk.Sampai pada tahap ini, seorang pemasar telah berhasil menciptakan kebutuhan calon pembeli.Sejumlah calon pembeli sudah mulai goyah dan emosinya mulai tersentuh.Namun demikian timbul perlawanan dalam diri calon pembeli berupa keraguan, benarkah produk atau jasa yang bersangkutan memberikan sesuatu seperti yang dijanjikan iklannya.

d. Action

Dalam tahapan yang paling pusat ini seorang pemasar haruslah sudah mengarah pada tindakan untuk membeli. Dalam tahapan action ini menjelaskan langkah apa yang dilakukan oleh seorang pemasar dalam menginginkan untuk pembaca atau target melakukan keputusan untuk membeli. Membimbing pembaca atau target karena pembaca atau target akan bertindak jika seorang pemasar menjelaskan langkahlangkahnya dan kadang juga perlu diinformasikan masalah harga untuk tindakan tersebut.

\section{Instagram}

Instagram merupakan salah satu media sosial yang dapat digunakan sebagai promosi produk atau jasa. menurut Salamoon (2013), media sosial instagram diciptakan sehingga para pemilik smartphone akan merasa bahwa kamera yang terpasang tidak sia-sia. Instagram adalah sebuah filter digital, dan membagikanya ke berbagai layanan jejaring sosial termasuk milik instagram sendiri. Salah satu fitur unik yang dimili instagram adalah memotong foto menjadi bentuk persegi, sehingga tampak seperti kamera kodak Instamatic dan polanoid. Selain itu Instagram juga bisa langsung terkoneksi dengan aplikasi media sosial yang lain seperti facebook dan twitter. Intagram juga mampu melakukan proses edit foto sebelum diunggah ke jaringan. Foto-foto yang diunggah juga tidak terbatas atasa jumlah tertentu. ${ }^{16}$

Instagram adalah salah satu media sosial paling popular yang digunakan digital native. Media sosial ini seakan telah mengambil sebagian kehidupan digital native sepanjang hari. Kelebihan fitur Instagram

\footnotetext{
${ }^{16}$ Maria Ulfa, "Efektifitas Instagram Dalam Mempromosikan Penjualan Kamar Batiqa Hotel Pekanbaru," Jom FISIP 5, no. 1, 2018, hlm. 1-14.
} 
memang membuat digital native betah berlama-lama menikmati fasilitas yang diberikan media sosial ini. Instagram menyediakan fitur posting edit foto snapgram (caption, filter, efek unik, dan stiker lucu), instastories, video pendek, bumerang, superzoom, rewind, handsfree, dan slow motion. Digital native juga senang membaca berita mutakhir tentang pendidikan, sosial, politik, dan gosip lewat link yang diberikan oleh akunakun Instagram yang mereka ikuti (follow). Mereka juga senang menikmati meme lucu, video tutorial, dan klip karaoke. Mereka juga senang menikmati fitur Instagram sambil saling mengirim dan membalas pesan antarsesama pengguna Instagram lainnya melalui Direct Message (DM). ${ }^{17}$

\section{Filantropi Islam}

Di antara organisasi-organisasi Islam, istilah filantropi adalah baru dan diperkenalkan melalui advokasi dan program penelitian Filantropi untuk Keadilan Sosial pada tahun 2002. Penerimaan istilah dan konsep ini tidak mudah karena dianggap sebagai sekuler dan Barat. Namun, sampai saat ini, istilah ini telah banyak

${ }^{17}$ Lucy Pujasari Supratman, "Penggunaan Media Sosial Oleh Digital Native," Jurnal Ilmu Komunikasi 15, no. 1 (2018): 47-60, https://ojs.uajy.ac.id/index.php/jik/article/view/1243/ 1152. hlm. 55 digunakan, termasuk oleh surat kabar Islam (seperti Republika) dan oleh organisasi zakat. Kata sifat 'sosial' ketika diterapkan pada keadilan mendukung penerimaan istilah filantropi. ${ }^{18}$

Di negara-negara mayoritas Muslim, pendekatan umum untuk "filantropi Islam" umumnya diarahkan pada bentuk-bentuk amal utama dalam ajaran Islam, yaitu tentang wakaf, zakat dan sadaqah sebagai tiga pilar utama filantropi Muslim. menurut Dwight Burlingame, untuk negara Barat, konsep amal dan filantropi tidak selalu hal yang terkait dengan Islam. Namun standar perilaku etika religius tersirat dalam kata-kata seperti 'kebaikan'," kemurahan hati , " cinta umat manusia, 'dan' kasih sayang. ${ }^{19}$

Istilah filantropi menyebar pada abad ke-5 SM di dunia Yunani klasik. Kata filantropi berasal dari kata Yunani phileo dan anthropos. Phileo berarti cinta atau aspek khusus cinta yang dalam bahasa Yunani kuno mewakili salah satu dari empat kelompok kata utama untuk mengungkapkan konsep cinta atau

\footnotetext{
${ }^{18}$ Amelia Fauzia, "Islamic Philanthropy in Indonesia: Modernization, Islamization, and Social Justice," Austrian Journal of South-East Asian Studies 10, no. 2, 2017, hlm. 223-237.

${ }^{19}$ Sherine El Taraboulsi, "Muslim Philanthropy And The Production Of Space: The Muslim Philanthropy Digital Library Case" (n.d.).
} 
keinginan; tiga lainnya adalah eros, stergõ, dan agape. Anthropos didefinisikan sebagai "manusia" dalam arti kata yang terluas, tanpa membedakan satu pun manusia. Istilah filantropi dapat didefinisikan sebagai keinginan manusia untuk membantu orang lain yang ditunjukkan dengan memberi atau tindakan amal sebagai bentuk dari cinta manusia. ${ }^{20}$

Istilah filantropi diartikan dengan rasa kecintaan kepada manusia yang terpatri dalam bentuk pemberian derma kepada orang lain. Filantropi juga dimaknai sebagai konseptualisasi dari praktik pemberian sumbangan sukarela (voluntary giving), penyediaan layanan sukarela (voluntary services) dan asosiasi sukarela (voluntary association) secara suka rela untuk membantu pihak lain yang membutuhkan sebagai ekspresi rasa cinta. Filantropi dalam arti pemberian derma biasa juga disamakan dengan istilah charity. ${ }^{21}$

Secara terminologi filantropi tidak dikenal diawal Islam, sekalipun
Fuadi,

"ISLAMIC PHILANTHROPY ON SOCIAL MEDIA : New Way to Inform, to Communicate, and to Promote Social Welfare in Indonesia ( The Case of \# SedekahRombongan /\# SR )" 12, no. 1, 2014, hlm. 21-36.

${ }^{21}$ Abdurrohman Kasdi, "Filantropi Islam Untuk Pemberdayaan Ekonomi Umat ( Model Pemberdayaan ZISWAF Di BMT Se-Kabupaten Demak )," Iqtishadia 9, no. 2, 2016, hlm. 227-245. belakangan para akademisi memberikan terminologi padanannya seperti, al-ata" al Ijtima" $i$ (pemberian sosial), al takaful al insani (solidaritas kemanusiaan), ata" khayri (pemberian untuk kebaikan), al-birr (perbuatan baik) dan shadaqah (sedekah). Dalam konteks ini, keberadaan filantropi Islam bentuk pengertian pemahamannya akan mengacu pada dua istilah yang terakhir diatas yang juga dikenal masa awal Islam, sekaligus pengadobsian istilah pada zaman modern, sehingga pada prinsipnya filantropi Islam adalah setiap kebaikan merupakan perbuatan shadaqah. ${ }^{22}$

Praktik pengelolaan filantropi Islam selama ini, juga banyak dilakukan oleh lembaga sosial kemasyarakatan, lembaga sosial keagamaan, lembaga pendidikan, lembaga filantropi profesional maupun bersifat komunitas tertentu. Urgensi filantropi dalam Islam dapat dilihat dari cara al-Qur'an menekankan keseimbangan antara mengeluarkan zakat dan menegakkan shalat. Selain zakat bentuk filantropi Islam yang lain adalah melalui Infaq, melalui sedekah dan wakaf.

\footnotetext{
${ }^{22}$ Makhrus, "Aktivisme Pemberdayaan Masyarakat Dan Institusionalisasi Filantropi Islam Di Indonesia."
} 


\section{METODE PENELITIAN}

Berdasarkan masalah yang dikaji dalam penelitian ini, maka jenis penelitian ini adalah penelitian kuantitatif. Tempat penelitian adalah IAIN Bengkulu khususnya mahasiswa program studi Manajemen Zakat dan Wakaf. Dalam penelitian ini unit analisis yang diambil yakni pada tataran individu, yaitu para mahasiswa yang memiliki jejaring sosial facebook dan Instagram yang mengetahui tentang adanya persuasi filantropi Islam melalui kedua jejaring sosial tersebut. ${ }^{23}$

Sumber data dalam penelitian ini adalah data $\operatorname{primer}^{24}$ yang diperoleh melalui kuesioner. Adapun jenis data pada penelitian ini menurut cara memperolehnya maka jenis data penelitian ini adalah data primer ${ }^{25}$.

Berdasarkan sumber data maka populasi pada penelitian ini adalah

${ }^{23}$ Slamet Dosen et al., "Efektifitas Komunikasi Dalam Dakwah Persuasif," Jurnal Dakwah X, no. 2 (n.d.): 179-193, http://digilib.uinsuka.ac.id/8374/1/SLAMET EFEKTIFITAS KOMUNIKASI DALAM DAKWAH PERSUASIF.pdf.

${ }^{24}$ Data primer, yaitu data yang dikumpulkan langsung oleh peneliti. Metode atau pendekatan yang dapat dilakukan dalam proses pengumpulan data yang bersifat primer ini dapat menggunakan angket/kuesioner, wawancara, pengamatan, tes, dokumentasi, dan sebagainya. (Suryani, 173)

${ }^{25}$ Jenis data primer adalah data yang dikumpulkan langsung dari objeknya. Pengumpulan data tersebut dilakukan secara khusus untuk mengatasi masalah riset yang sedang diteliti. (Suryani and Hendriyadi, Metode Riset Kuantitatif: Teori Dan Aplikasi Pada Penelitian Bidang Manajemen Dan Ekonomi Islam. (Jakarta: Prenada Media Group, 2015), hlm.171) populasi terbatas $^{26}$ dan jika dilihat dari segi kompleksitas objek populasi, maka populasi pada penelitian ini adalah populasi heterogen ${ }^{27}$ karena populasi pada penelitian ini adalah semua mahasiswa program studi zakat dan wakaf yang terdiri dari 76 Orang.

Adapun teknik sampling pada penelitian ini adalah nonprobability sampling artinya tidak semua unit populasi memiliki kesempatan untuk dijadikan sampel penelitian hal ini karena sifat populasi itu sendiri yang heterogen sehingga terdapat diskriminasi tertentu dalam unit-unit populasi. $^{28}$ Pada penelitian ini menggunakan teknik sampling jenuh dengan besaran sample seluruh populasi pada penelitian.

Pada penelitian ini menggunakan metode pengumpulan data cara survei. Pada proses pengumpulan data akan

\footnotetext{
${ }^{26}$ Populasi terbatas yaitu, populasi yang memiliki sumber data yang jelas batas-batasnya secara kuantitatif.

${ }^{27}$ Dari segi kompleksitas objek populasi, maka populasi dapat dibedakan menjadi populasi homogen dan populasi heterogen. Populasi homogen adalah keseluruhan individu yang menjadi anggota populasi, memiliki sifat-siafat relatif sama satu sama lainnya. Sifat populasi seperti ini banyak dijumpai pada medan eksata, contohnya air. Sedangkan populasi heterogen adalah keseluruhan individu anggota populasi relatif memiliki sifat-sifat individual, dimana sifat tersebut membedakan individu anggota populasi yang satu dengan yang lainnya. Dengan kata lain anggota populasi memiliki sifat yang bervariasi sehingga memerlukan penjelasan terhadap sifat-sifat tersebut baik secara kuantitatif maupun kualitatif. (Burhan Bungin, hlm. 109-110)

${ }^{28}$ Burhan Bungin, Metodologi Penelitian Kuantitatif (Jakarta: Jakarta, 2005).
} 
digunakan instrumen pengumpul data ${ }^{29}$. Adapun instrumen yang digunakan pada penelitian ini adalah kuesioner. Kuesioner ini digunakan untuk mengetahui tingkat efektifitas Instagram sebagai media persuasi filantropi Islam bagi mahasiswa. Kuesioner diberikan kepada mahasiswa program Studi Zakat dan Wakaf.

Penelitian ini menggunakan pendekatan kuantitatif dengan ini menggunakan analisis data deskriptif dengan menjelaskan data data yang diperoleh melalui kuesioner untuk menjelaskan tingkat efektivitas persuasi dengan analisis AIDA (attention, interest, desire dan action). Dalam pengisian jawaban kuesioner, jawaban "sangat setuju" akan menunjukkan nilai 5, jawaban "setuju" akan menunjukkan nilai 4, jawaban " Cukup Setuju” akan menunjukkan nilai 3, jawaban “ Tidak Setuju" akan menunjukkan nilai 2, dan jawaban "Sangat Tidak Setuju" akan menunjukkan nilai 1 .

Data yang diperoleh tersebut selanjutnya dianalisis dengan menghitung total jawaban secara manual. Menurut

\footnotetext{
${ }^{29}$ Instrumen pengumpul data merupakan alat yang digunakan untuk mengumpulkan data. Karena berupa alat, maka instrumen dapat berupa lembar cek list, kuesioner (angket terbuka/tertutup), pedoman wawancara, camera photo, video camera, buku catatan, dan lain sebagainya. ( Suryani and Hendriyadi, hlm. 173).
}

Paulus (2011), jika jawaban-jawaban yang diperoleh memiliki rata-rata nilai

1. $0-20 \%$ berarti efektivitas iklan berada pada kriteria "Buruk",

2. $21-40 \%$ berada pada kriteria "Menengah",

3. $41-60 \%$ berada pada kriteria " Ratarata",

4. 61-80\% berada pada kriteria "Baik"

5. $81-100 \%$ berada pada kriteria "Istimewa"

Untuk melakukan analisis data maka data yang diperoleh diringkas dan dibandingkan dengan indikator-indikator yang telah ditetapkan dalam kuesioner. Perhitungan atas kuesioner dilaksanakan dengan menggunakan analisis AIDA. Menurut Paulus (2011) metode analisis AIDA menggunakan rumus sebagai berikut.

$X=\quad$ Total Nilai $\quad X 100 \%$

Total Nilai Penuh Harapan Xn

Keterangan :

X1 = Nilai pada tahap attention

$\mathrm{X} 2=$ Nilai pada tahap interest

$\mathrm{X} 3$ = nilai pada tahap desire

$\mathrm{X} 4=$ nilai pada tahap action

$\mathrm{Xn}=$ nilai pada masing-masing tahap hierarki AIDA

\section{PEMBAHASAN}

Fundraising adalah proses mempengaruhi masyarakat baik perorangan atau lembaga agar menyalurkan dana, sumber daya non- 
dana, simpati atau dukungan kepada komunitas. Inti fundraising adalah menawarkan program unggulan atau kualitas kinerja lembaga/komunitas kepada masyarakat (donatur), sehingga masyarakat dapat mendukung dan berpartisipasi. Jadi mencermati pengertian ini bahwa fundraising bukanlah membudayakan meminta-minta kepada orang lain, namun menawarkan program kerja kepada mitra. ${ }^{30}$ Salah satu langkah lembaga filantropi dalam fundraising melalui media social. Media social adalah media yang sangat dekat dengan generasi muda misalnya mahasiswa.

Populasi dari penelitian ini adalah seluruh mahasiswa program studi zakat dan wakaf. Sampel yang digunakan adalah sampel jenuh, sehingga jumlah sampel pada penelitian ini yaitu sebanyak 76 Orang Mahasiswa. Dari total 76 Responden mahasiswa, 12 Orang tidak mengikuti akun instagram manapun yang memiliki ajakan filantropi Islam, sehingga hanya 64 Responden yang diteliti. Dalam sehari setiap responden pasti membuka akun Instagram yang dimilikinya, dengan rincian sebagai berikut:
Tabel 1

Jumlah Responden berdasarkan Durasi Waktu melihat Instagram

\begin{tabular}{|c|l|l|}
\hline NO & DURASI WAKTU & JUMLAH \\
\hline 1 & $<1$ Jam & 4 Orang \\
\hline 2 & $1-3$ Jam & 35 Orang \\
\hline 3 & $>3$ Jam & 12 Orang \\
\hline
\end{tabular}

Sumber : Data Primer yang diolah penulis (2018)

Dari data di atas diperoleh data bahwa sebanyak $35 \%$ responden membuka akun media social selam 1-3 Jam dalam sehari. Hal ini menunjukkan bahwa membaca informasi melalui media social memiliki daya tariknya tersendiri.

Akun instagram yang memiliki ajakan filantropi Islam yang diikuti responden, yaitu:

\section{Tabel 2}

Jumlah Responden berdasarkan Jumlah Instagram/lembaga yang diikuti

\begin{tabular}{|l|l|l|}
\hline NO & NAMA LEMBAGA & JUMLAH \\
\hline 1 & ACT/ MRI & 40 \\
\hline 2 & BAZNAS & 32 \\
\hline 3 & RUMAH ZAKAT & 20 \\
\hline 4 & BMH BENGKULU & 21 \\
\hline 5 & TIDAK ADA & 12 \\
\hline
\end{tabular}

Sumber : Data Primer yang diolah penulis (2018)

Dari data di atas diketahui bahwa mayoritas mahasiswa mengikuti akun instagram ACT, hal ini karena di wilayah Bengkulu terdapat MRI Bengkulu dan terdapat beberapa mahasiswa Fakultas Ekonomi dan Bisnis Islam IAIN Bengkulu merupakan Relawan MRI.

\footnotetext{
${ }^{30}$ Drina Intyaswati, "Pesan Komunikasi Dalam Penggalangan Dana” (2010).
} 
Sehingga ACT/ MRI lebih dikenal $\mathrm{X}=$

mahasiswa.

Untuk analisis data yang menjadi parameter efektitivitas ajakan filantropi islam melalui media sosial instagram yaitu konsep AIDA yang meliputi Attention, Interest, Desire, Action. Pengukuran tahapan AIDA tersebut diwakili oleh 16 pertanyaan dalam kuesioner dan selanjutnya diolah dengan rumus tabulasi sederhana dan skor ratarata. Adapun perhitungannya sebagai berikut:

1. Attention

Tabel 3

Skor Responden Kategori Attention pada Instagram

\begin{tabular}{|c|c|c|c|c|}
\hline \multirow{2}{*}{ SKOR (wi) } & \multicolumn{4}{|c|}{ PERTANYAAN } \\
\cline { 2 - 5 } & $\mathrm{f} 1$ & $\mathrm{f} 2$ & $\mathrm{f} 3$ & $\mathrm{f} 4$ \\
\hline 1 & 2 & 1 & 1 & 1 \\
\hline 2 & 0 & 1 & 0 & 0 \\
\hline 3 & 5 & 4 & 3 & 2 \\
\hline 4 & 19 & 20 & 19 & 17 \\
\hline 5 & 38 & 38 & 41 & 44 \\
\hline \begin{tabular}{|l|} 
JUMLAH \\
RESPONDEN
\end{tabular} & \multicolumn{5}{|c}{} \\
\hline
\end{tabular}

Sumber : Data Primer yang diolah penulis (2018)

Dari data diatas maka perhitungan

nilai Efektifitas Attention pada Instagram, yaitu:

$$
\mathrm{X}=\frac{\text { Total Nilai }}{\text { Total Nilai Penuh Harapan Xn }} \mathrm{X} \mathrm{100 \%}
$$

$\frac{805}{1280} \times 100 \%$

$X=62,1 \%$

Dalam attention ini lembaga filantropi haruslah mampu membuat sebuah media informasi agar mengandung daya tarik bagi donatur. Membuat suatu pernyataan yang mengungkap perhatian orang, membuat kata atau gambar yang powerful yang bisa menarik perhatian hingga orang berhenti dan memperhatikan isi pesan berikutnya.

Attention merupakan suatu bentuk perhatian yang dilakukan oleh responden dalam menanggapi suatu bentuk persuasi filantropi Islam melalui media soisal Instagram. Perhatian yang dimaksud adalah respon responden terhadap kehadiran Instagram yang didalamnya memiliki ajakan untuk melaksanakan kewajiban zakat atau melaksanakan infaq, sedekah dan wakaf. Tingkat efektifitas Instagram berada pada kriteria baik, hal ini ditunjukkan berdasarkan hasil perhitungan yaitu sebesar $62,9 \%$.

Kehadiran Instagram yang didalamnya memiliki ajakan untuk melaksanakan kewajiban zakat atau melaksanakan infaq, sedekah dan Wakaf telah meningkatkan pengetahuan responden mengenai keberadaan lembaga Filantropi Islam. 
2. Interest

Tabel 4

Skor Responden Kategori Interest pada Instagram

\begin{tabular}{|c|c|c|c|c|}
\hline \multirow{2}{*}{ SKOR (wi) } & \multicolumn{3}{|c|}{ PERTANYAAN } \\
\cline { 2 - 5 } & f1 & f2 & f3 & f4 \\
\hline 1 & 4 & 7 & 1 & 3 \\
\hline 2 & 3 & 3 & 2 & 3 \\
\hline 3 & 3 & 3 & 4 & 11 \\
\hline 4 & 12 & 12 & 14 & 13 \\
\hline 5 & 42 & 39 & 43 & 34 \\
\hline $\begin{array}{c}\text { JUMLAH } \\
\text { RESPONDEN }\end{array}$ & \multicolumn{5}{|c}{64} \\
\hline
\end{tabular}

Sumber : Data Primer yang diolah penulis (2018)

Dari data diatas maka perhitungan nilai

Efektifitas Interest pada Instagram, yaitu:

$$
\mathrm{X}=\frac{\text { Total Nilai }}{\text { Total Nilai Penuh Harapan Xn }} \mathrm{X} 100 \%
$$$$
X=\frac{790}{1280} \quad X 100 \%
$$

$X=61,7 \%$

Interest adalah langkah setelah lembaga filantropi mampu untuk membuat sebuah media informasi tersebut agar dapat mengandung daya tarik bagi donatur, lembaga filantropi haruslah memikirkan sebuah media informasi agar dapat mengandung minat bagi calon donaturnya tersebut. Kebanyakan media informasi yang buruk melalaikan dalam melakukan tahapan ini, ditahap inilah sebenarnya donatur bersedia memberikan waktunya untuk membaca pesan dari pemasar lebih detail.

Interest merupakan tahap yang menguji sejauh mana ketertarikan responden terhadap persuasi yang dipromosikan melalui Instagram. Tidak semua responden akan mencapai tahap interest, karena capaian responden akan berbeda-beda tergantung individu masing-masing. Setelah tahapan attention, reaksi responden akan mencerminkan apakah responden tersebut ingin mengetahui lebih lanjut lagi atau tidak.

Pada penelitian ini Instagram yang didalamnya memiliki ajakan untuk melaksanakan kewajiban zakat atau melaksanakan infaq berada pada kategori baik. Hal ini menunjukkan bahwa persuasi melalui Instagram dapat meningkatkan keinginan responden untuk mengetahui lebeih lanjut mengenai persuasi melalui Instagram. Karena persuasi melalui Instagram memiliki keunggulan tersendiri terutama penampilan pada gambar yang merupakan bukti bahwa dana yang disalurkan oleh para donatur benar-benar telah disalurkan ke tempat yang tepat. 


\section{Desire}

Tabel 5

Skor Responden Kategori Desire pada Instagram

\begin{tabular}{|c|c|c|c|c|}
\hline \multirow{2}{*}{ SKOR (wi) } & \multicolumn{4}{|c|}{ PERTANYAAN } \\
\cline { 2 - 5 } & $\mathrm{f} 1$ & $\mathrm{f} 2$ & $\mathrm{f} 3$ & $\mathrm{f} 4$ \\
\hline 1 & 0 & 1 & 0 & 2 \\
\hline 2 & 0 & 1 & 0 & 3 \\
\hline 3 & 6 & 3 & 5 & 3 \\
\hline 4 & 17 & 15 & 21 & 18 \\
\hline 5 & 41 & 44 & 38 & 38 \\
\hline JUMLAH & \multicolumn{5}{|c}{64} \\
RESPONDEN
\end{tabular}

Sumber : Data Primer yang diolah penulis (2018)

Dari data diatas maka perhitungan nilai Efektifitas Desire pada Instagram, yaitu:

$\mathrm{X}=\quad$ Total Nilai $\quad \mathrm{X} 100 \%$

Total Nilai Penuh Harapan Xn

$X=\frac{805}{1280} \times 100 \%$

$X=62,9 \%$

Desire merupakan tahapan ketiga setelah attention dan juga interest. Desire merupakan bentuk keinginan responden untuk melakukan donasi karena persuasi yang dilakukan oleh lembaga filantropi Islam melalui media social Instagram, hal ini dapat dilihat dengan melakukan interaksi baik secara langsung ataupun melalui media sosial. Interaksi yang dilakukan tersebut bertujuan untuk menggali lebih banyak lagi informasi. Informasi yang dimaksud kemungkinan merupakan informasi yang tidak tersedia pada media sosial atau informasi tidak dapat dipahami oleh responden.

Pada tahapan desire persuasi melalui instagram berada pada kategori baik dengan angka menunjukkan 62,9\%. Hal tersebut menandakan bahwa responden yang mengirimkan komentar, menghubungi contact person, melakukan screenshoot atau menyimpan foto, dan mencari testimoni sebagai bahan referensi tergolong banyak

4. Action

Tabel 6

Skor Responden Kategori Action pada Instagram

\begin{tabular}{|c|l|l|l|l|}
\hline \multirow{2}{*}{ SKOR (wi) } & \multicolumn{4}{|c|}{ PERTANYAAN } \\
\cline { 2 - 6 } & f1 & f2 & f3 & f4 \\
\hline 1 & 7 & 1 & 0 & 2 \\
\hline 2 & 2 & 0 & 2 & 2 \\
\hline 3 & 2 & 12 & 4 & 3 \\
\hline 4 & 9 & 17 & 19 & 11 \\
\hline 5 & 44 & 34 & 39 & 46 \\
\hline $\begin{array}{c}\text { JUMLAH } \\
\text { RESPONDEN }\end{array}$ & \multicolumn{5}{|c}{64} \\
\hline
\end{tabular}

Sumber : Data Primer yang diolah penulis (2018)

Dari data diatas maka perhitungan

nilai Efektifitas Action pada Instagram, yaitu:

$X=\quad$ Total Nilai $\quad$ X 100\%

Total Nilai Penuh Harapan Xn 
$\mathrm{X}=$ 815

X $100 \%$

1280

$X=63,7 \%$

Action merupakan tahapan terakhir dalam tahapan AIDA. Pada tahapan ini, responden sudah merencanakan donasi atas persuasi filantropi Islam yang dilihat responden pada media social Instagram. Action mendorong tindakan responden untuk segera berdonasi pada persuasi tersebut, tidak hanya melihat dan membaca.

Pada tahapan yang terakhir ini atau pada action tingkat efektifitas ajakan melalui instagram sebesar $63,7 \%$, hal ini menunjukkan persuasi melalui media social instagram berada pada kategori Baik. Hal ini dibuktikan sebanyak 45 orang mahasiswa pernah melakukan donasi karena persuasi tersebut melalui facebook.

Secara keseluruhan tingkat efektifitas persuasi filantropi Islam yang diukur dengan AIDA berada pada kategori baik bagi generasi muda. Hal ini dikarenakan media social merupakan media yang paling dekat dengan generasi muda.

Tapscott menguraikan tentang generasi internet di Amerika yang terbagi ke dalam empat kelompok generasi. Pertama, generasi baby boom (Januari 1946-Desember 1964) yang berlangsung selama 19 tahun dan menghasilkan 77,2 juta anak atau $23 \%$ jumlah penduduk. Kedua, generasi X (Januari 1965Desember 1976) yang berlangsung selama 12 tahun dan menghasilkan 44,9 juta anak atau $15 \%$ jumlah penduduk. Kelompok ini juga disebut baby bust. Ketiga, generasi internet (Januari 1977Desember 1997) yang berlangsung selama 21 tahun dan menghasilkan sekitar 81.1 juta anak atau 27\% jumlah penduduk. Kelompok ini juga disebut generasi milenial atau generasi $\mathrm{Y}$. Keempat, generasi Z yang (Januari 1998sekarang). Generasi milenial dan generasi $\mathrm{Z}$ masuk dalam kaum digital native yang menghabiskan hampir seluruh waktunya untuk berinteraksi melalui media sosial. ${ }^{31}$

Setiap hari, digital native menghabiskan $79 \%$ waktunya untuk mengakses internet. Data tersebut sebenarnya telah menjadi pemandangan umum di sekeliling masyarakat kita saat menyaksikan aktivitas digital native yang senang berlama-lama menggunakan media sosial. $^{32}$

Salah satu bentuk modal sosial dan kearifan lokal yang bisa menjadi solusi dalam menanggulangi kemiskinan khususnya umat Islam adalah lembaga zakat, infak, dan sedekah (ZIS). Dana ZIS kalau dikelola secara baik akan

\footnotetext{
${ }^{31}$ Supratman, "Penggunaan Media Sosial Oleh Digital Native.” hlm. 49

${ }^{32}$ Ibid.
} 
memperkecil penyebab kemiskinan bahkan bisa mengentaskan kemiskinan melalui pemberdayaan masyarakat miskin. Dengan demikian dana zakat, infak dan sedekah (ZIS) bisa digunakan untuk memberi mereka (penduduk miskin) peluang kerja melalui pemberian bantuan modal atau alat produksi, bantuan pelatihan dan sebagainya. ${ }^{33}$

Selain memiliki arti penting religius zakat memainkan peranan amat penting dalam kehidupan sosial-ekonomi kaum muslimin. Zakat adalah batu penjuru bagi struktur financial negara Islam. Zakat tidak hanya memberi dana yang diperlukan oleh negara Islam bagi kegiatan kesejahteraannya di sektorsektor seperti pendidikan, kesehatan, dan jasa-jasa sosial, melainkan juga memungkinkannya memenuhi semua kewajibannya dalam hubungannya dengan warganya yang miskin dan papa. $^{34}$

Zakat bukan semata-mata urusan agama yang tidak terkait de- ngan kebijakan Negara dan kepemimpinan. Para pemimpin perlu menyadari bahwa zakat adalah potensi dan kekuatan yang dapat menggerakkan perekonomian dan

\footnotetext{
${ }^{33}$ AF Agustin, K Ashar, and M Multifiah, "Identifikasi Modal Sosial Pada Program Pemberdayaan Masyarakat Miskin Melalui Dana Zakat, Infak Dan Sedekah," Iqtishoduna, no. 1, 2013, hlm. 1-8.

${ }^{34}$ Muhammad Sharif Chaudhry, Sistem Ekonomi Islam (Jakarta: Kencana, 2016), hlm.85
}

mengatasi kesenjangan sosial. Jika kaum dhuafa diberdayakan maka dengan sendirinya perekonomian negara akan terselamatkan dari ke senjangan. ${ }^{35}$

\section{E. KESIMPULAN}

Tingkat efektifitas persuasi melalui Instagram berada pada kategori baik, hasil ini diperoleh dengan menggunakan analisis tingkat efektifitas AIDA.

Beberapa saran yang diajukan penulis diantaranya yaitu, bagi Mahasiswa untuk dapat memanfaatkan Instagram sebagai sarana menambah pengetahuan dalam bidang filantropi Islam.

Bagi Lembaga filantopi untuk meningkatkan penggunaan Instagram sebagai sarana meningkatkan penghimpunan dana kebajikan terutama bagi generasi muda.

Bagi peneliti selanjutnya, melalui penelitian ini dapat menambah variabel lainnya selain persuasi.

\section{DAFTAR PUSTAKA}

Agustin, AF, K Ashar, and M Multifiah. "Identifikasi Modal Sosial Pada Program Pemberdayaan Masyarakat Miskin Melalui Dana Zakat, Infak Dan Sedekah." Iqtishoduna, no. 1 (2013): $1-8$.

Bungin, Burhan. Metodologi Penelitian Kuantitatif. Jakarta: Jakarta, 2005.

Chaudhry, Muhammad Sharif. Sistem

\footnotetext{
${ }^{35}$ Zakat Dan and Etos Kerja, "BUDAYA BANGSA Zakat Dan” (2014).
} 
Ekonomi Islam. Jakarta: Kencana, 2016.

Dan, Zakat, and Etos Kerja. "BUDAYA BANGSA Zakat Dan” (2014).

Dosen, Slamet, Fakultas Dakwah, Uin Sunan, and Kaljaga Yogyakarta. "Efektifitas Komunikasi Dalam Dakwah Persuasif." Jurnal Dakwah X, no. 2 (n.d.): 179-193. http://digilib.uin-

suka.ac.id/8374/1/SLAMET

EFEKTIFITAS KOMUNIKASI

DALAM

DAKWAH

PERSUASIF.pdf.

Fauzia, Amelia. "Islamic Philanthropy in Indonesia: Modernization, Islamization, and Social Justice." Austrian Journal of South-East Asian Studies 10, no. 2 (2017): 223-237.

Fuadi, Ariza. "ISLAMIC PHILANTHROPY ON SOCIAL MEDIA : New Way to Inform, to Communicate, and to Promote Social Welfare in Indonesia ( The Case of \# SedekahRombongan /\# SR )" 12, no. 1 (2014): 21-36.

Intyaswati, Drina. "Pesan Komunikasi Dalam Penggalangan Dana" (2010).

Jinan, Muhammad. "Intervensi New Media Dan Impersonalisasi Otoritas Keagamaan Di Indonesia." Jurnal Komunikasi Islam 03, no. 02 (2013): 321-348.

Kasdi, Abdurrohman. "Filantropi Islam Untuk Pemberdayaan Ekonomi Umat ( Model Pemberdayaan ZISWAF Di BMT Se-Kabupaten Demak )." Iqtishadia 9, no. 2 (2016): 227-245.

Makhrus. "Aktivisme Pemberdayaan Masyarakat Dan Institusionalisasi Filantropi Islam Di Indonesia." Islamadina 13, no. 2 (2014): 26-44.

Maria Ulfa. "Efektifitas Instagram Dalam Mempromosikan Penjualan Kamar Batiqa Hotel Pekanbaru." Jom FISIP 5, no. 1 (2018): 1-14.

Nida, Fatma Laili Khoirun. "Persuasi Dalam
Media Komunikasi Massa." AtTabsyir, Jurnal Komunikasi Penyiaran Islam 2, no. 2 (2014): 77-95.

Supratman, Lucy Pujasari. "Penggunaan Media Sosial Oleh Digital Native." Jurnal Ilmu Komunikasi 15, no. 1 (2018): 47-60. https://ojs.uajy.ac.id/index.php/jik/arti cle/view/1243/1152.

Taraboulsi, Sherine El. "Muslim Philanthropy And The Production Of Space: The Muslim Philanthropy Digital Library Case" (n.d.).

Udin Saripudin. "Filantropi Islam.” Bisnis 4, no. 2 (n.d.): $165-185$. http://mhakicky.blogspot.com/2012/11 /filantropi-islam.html.

Yulkardi, Wahyu Pramono, Agus Budiono, and Yunarti. "Filantropi Untuk Keadilan Sosial: Sebuah Studi Pendahuluan Tentang Potensi Dan Pola Derma Pada Masyarakat Minangkabau Dan Kemungkinan Pengembangannya Untuk Keadilan Sosial." Jurnal Antropologi, Isu-Isu Sosial Budaya 1, no. 14 (2014): 3338.

http://jurnalantropologi.fisip.unand.ac. id/index.php/jantro/article/view/4. 